eventually, therefore, on the composition of the soluble components of the soil and the manures applied. $\mathrm{Mr}_{\mathrm{r}}$. R. N. Lyne presented a paper on the causes contributing to the success of the Zanzibar clove industry, in which the importance of soil and climate in this connection was insisted on, and not less the success of the Arab proprietors of the plantations in accommodating their business methods to the habits of the native population.

Dr. S. S. Pickles submitted a paper in which the characters and composition of the essential oils obtained from a large number of Cymbopogon grasses grown in Ceylon were given. These results are of great importance in connection with Dr. Stapf's recent botanical revision of this genus.

In section 2 the principal topic of discussion was the essential factors in the acclimatisation of European cattle in the tropics, on which useful reports were submitted by M. Meuleman, who is General-Reporter for this inquiry, M. Douarche, of Tonquin, M. Peralta for Costa Rica, Mr. Jarvis for Rhodesia, and Prof. Carmody for Trinidad. The only general paper read in this section was one by Mr. Barwick, of the Imperial Institute, on African wild silks.

The papers submitted in section 3 were of economic and administrative importance rather than of scientific interest, though reference may be made to the reports, mainly by officials in British colonies, submitted by M. Batalha-Reis on agricultural labour conditions in the tropics.

During the congress a special meeting of the International Association of Colonial Agriculture was held, at which Prof. Wyndham Dunstan, director of the Imperial Institute, was elected president of the association in succession to $M$. de Lanessan, formerly Governor of IndoChina, who had held this office since the foundation of the association in 1905 .

\section{INDIAN PALAENTOLOGY.}

THE Geological Survey of India continues to publish well-illustrated and exhaustive memoirs on the fossil invertebrate faunas of the region with which it deals. Two more on the Himalayan Trias have lately appeared, and are of much interest for study in connection with recent work on the Triassic fossils of other areas. The first memoir (Palaeontologia Indica, ser. 15, vol. vi. No. I, I909), on the Lower Triassic Cephalopoda from Spiti, Malla Johar, and Byans, was begun several years ago by the late $\mathrm{A}$. von Krafft, who collected much of the material. It has now been revised, completed, and brought up to date by Prof. C. Diener. It begins with a synopsis of the marine Lower Triassic formations of the Himalayas, which are proved to constitute a remarkably complete series. The detailed descriptions of the fossils which follow show that at least four distinct and successive faunas occur in the rocks of the district under consideration. Of these, the lowest or earliest is perhaps the most interesting, because it seems to represent the dawn of Triassic life in the sea. It is noteworthy for the complete absence of the numerous types of Palæozoic Brachiopoda, which are the predominating element in the Permian rocks of the Salt Range and the Himalayas. Both in the Alps and in the Himalayas the Permian and Trias are connected by an uninterrupted sequence of sedimentary deposits. The second memoir, by Prof. Diener (loc. cit. No. 2), is more special, treating of the fauna, chiefly Cephalopoda, of the Thaumatocrinus Limestone of Painkhanda. $\mathrm{He}$ returns to a discussion of the age of this limestone, and shows that enough of its ammonites are identical with (or closely allied to) species found in Europe to justify its correlation with the Julic horizon, or zone of Trachyceras aonoides.

Another memoir just received from the Geological Survey of India, though dated 1908 , contains a valuable description of the Devonian faunas of the northern Shan States, by Mr. F. R. Cowper Reed (Palaeontologia Indica, N.S. vol. ii., No. 5). The fossils are chiefly corals, Bryozoa, and Brachiopoda, with only few representatives of other groups, but they constitute the richest collection of Devonian age hitherto described from south-eastern Asia. Most of them were obtained from Padaukpin, and many appear to be identical with European species which characterise the lower part of the Middle Devonian. The marine faunas of Middle and Upper Devonian times prove to have been remarkably cosmopolitan; but in all cases, as at Padaukpin and other places in eastern Asia, there is also a local element giving them a special character.

\section{UNIVERSITY AND EDUCATIONAL INTELLIGENCE.}

Cambrivge.-Mr. R. H. Rastall, of Christ's College, has been appointed additional demonstrator in geology from June I, I9ro, to May 3I, 1915.

The electors to the Frank Smart studentship in botany give notice that they will shortly proceed to the election of a student. Any graduate of the university is eligible for the studentship, provided that not more than fourteen complete terms have elapsed after his first term of residence. The successful candidate must devote himself to research in botany under the direction of the professor of botany. The studentship is ordinarily tenable for two years. The student is in special cases eligible for reappointment for a third year; he may be appointed for one year only. The value of the studentship is rool. per annum. A candidate must send his name, with a statement of the course of research which he proposes to undertake, and such evidence of his qualifications as he thinks fit, to the Vice-Chancellor, Pembroke College Lodge, on or before Tuesday, June 21 .

OXFORD.--In a convocation held on Tuesday afternoon, June 7 , in the Sheldonian Theatre, the Chancellor of the University, Lord Curzon of Kedleston, presiding, the honorary degree of D.C.L. was conferred on ex-President Roosevelt, who then proceeded to deliver the Romanes lecture. Taking as the subject of his discourse "Biolosical Analogies in History,"Mr. Roosevelt enlarged upon the phenomena of the rise and extinction of species, especially instancing the history of the mammalian fauna of South America from the Eocene epoch onwards, and drawing parallels between the changes taking place in the course of evolution among the lower animals, and the vicissitudes of human political societies. The treatment of the subject was interesting and suggestive, and the lecturer met with a cordial reception.

A TELEGRAM from the Times Ottawa correspondent on June 2 announced that a commission has been appointed by Federal authority to investigate the need for technical education in Canada. Mr. J. W. Robertson, late principal of the McDonald Agricultural College, has been appointed chairman of the commission.

THE current issue of the Battersea Polytechnic Magazine is a double number, with an unusually varied and interesting table of contents. Instances are given in one of the articles of the lively interest shown by King George and the late King in the work of the polytechnic. Among other contributions are an account of Brennan's monorail, and the biological disposal of sewage. The reports of the doings of the clubs and societies of the polytechnic are good evidence of the activity of the institution.

By the will of the late Mr. Isaac C. Wyman, of Salem, Mass., a graduate of Princeton College, who died on May is last, most of his estate, says Science, is bequeathed to Princeton University. The daily papers estimate the value of the bequest to be from $400,000 l$. to $2,000,000 l$. From the same source we learn that the Jefferson Medical College of Philadelphia has received a gift of $12,000 l$. from Mrs. M. G. Horwitz, daughter of the late Prof. S. D. Gross, to endow the "Samuel D. Gross Chair of Surgery."

THE fifth issue of the "Girls' School Year Book (Public Schools) " is now available, and it may be remarked that the annual is, for the first time, the official book of reference of the Association of Head Mistresses. The book continues to be useful, providing parents, schoolmistresses, and girls themselves, as it does, with trustworthy information respecting secondary education for girls. The second part of the work deals chiefly with the future career of girls on leaving school, and will appeal specially to parents and guardians, since the particulars given are of a thoroughly practical nature. 